\title{
Morphological and biochemical cow blood parameters fed with forest products and an enzyme preparation
}

\author{
Vera Tereshchenko*, Olga Ivanova, Evgeny Ivanov, and Lyubov Efimova
}

\begin{abstract}
Krasnoyarsk Research Institute of Animal Husbandry - Separate Division of the Federal State Budget Scientific Institution "Federal Research Center "Krasnoyarsk Science Center of the Siberian Branch of the Russian Academy of Sciences", 660049, Krasnoyarsk, Russia
\end{abstract}

\begin{abstract}
In order to improve the productivity of lactating cows and preserve their health, scientists and practitioners are searching for complex feed additives that have valuable biological properties. An experiment aimed to study the effect of feeding coniferous flour, pine nutshell, arabinogalactan, and enzyme preparation Amilosubtilin G3x on the biochemical and hematological parameters was conducted in the LLC "Plemzavod "Taezhny" of the Krasnoyarsk region. According to the principle of analogs, three groups of dairy black-motley cows including 15 animals were formed. The experiment lasted 100 days. The diet for cows of the control group was basic, experimental group 1 was fed with coniferous flour ( $50 \mathrm{~g} / \mathrm{goal} /$ day), cedar nutshell $(50 \mathrm{~g} / \mathrm{goal} /$ day), Amilosubtilin G3x (5 g / goal / day), cows of experimental group 2 were fed with coniferous flour (50 g / goal / day), pine nutshell (50 g / goal / day), Amilosubtilin G3x (5 g / goal / day), and arabinogalactan ( $5 \mathrm{~g} /$ goal / day). It was found that the additives did not have a negative effect on the metabolism, but improved blood counts. In the blood of experimental group 2, the concentration of total protein was higher by $2.7 \%$ and $2.0 \%$, albumin - by 3.0 and $1.0 \%$, calcium - by 1,5 and $6.3 \%$, phosphorus - by 10.2 and $10.7 \%$, creatinine - by 6.0 and $16.5 \%$, glucose - by 4.0 and $2.8 \%$, triglycerides - by $11.1 \%$ in comparison with the control group and experimental group 1 , respectively. The results obtained indicate that the additives can be used for feeding cows.
\end{abstract}

\section{Introduction}

Effective livestock farming is impossible without the rational use of feed, which should provide animals with energy, nutritious and biologically active substances, and improve productivity $[1,2]$.

Feeding of dairy cows, adapted to the physiological state and biochemical processes, is a key point in achieving success and profitability of milk production [3].

The efficiency of feed depends on a variety of highquality feed components and biologically active additives that can stimulate metabolic processes, general homeostasis, cicatricial digestion, ensure their high productivity and maximize their genetic potential [4]. Siberian forests are a source of diverse forest biomass containing a large number of valuable biologically active substances.

Krasnoyarsk region is one of the most forested regions of the Russian Federation. The total volume of forest reserves is approximately $6 \%$ of the world one. The total area of land occupied by forests is 163955 thousand ha $(45.1 \%)$. Moreover, the share of coniferous forests is $75.9 \%$ (pine, larch, cedar) [5].

The issue of the integrated use of all forest biomass is crucial [6]. Deep and complex processing of forest raw materials, logging waste from logging is not sufficiently developed due to outdated production capacities [7]. At the same time, the use of forest resources in feeding farm animals is an urgent area [6].

The most economically valuable coniferous species is pine, which is the main object of logging. Pine needles are non-timber forest resources, considered waste. However, there are numerous data on their use in feeding farm animals [8-10].

The value of needles for feeding animals is due to the fact that it contains carotenoids (carotenes and xanthophylls), chlorophylls, phytosterols, vitamins (C, E, $\mathrm{K}$, group B), sugar (glucose, fructose), pectin, tannins, amino acids (lysine, methionine, tryptophan, arginine, histidine, valine, isoleucine), macro- and microelements (cobalt, copper, manganese, zinc, iron) [11]. Phenolic compounds are involved in processes that counteract oxidative stress, and the rate of digestion of needles is $25-80 \%[12,13]$.

Flour from needles contains a large number of volatile, has a bactericidal effect, contributing to the prevention of intestinal diseases. The addition of coniferous flour in the diet of animals and birds has a positive effect on their growth and development, reduces mortality, and prevents vitamin deficiency.

\footnotetext{
* Corresponding author: krasniptig75@yandex.ru
} 
Scientists and practitioners suggesting adding needles into the diets of animals in small quantities and after special preliminary preparation (extraction of harmful substances: essential oils, resins, glucosides, tannides) $[14,15]$.

No less valuable for economic use is larch wood, which is rich in polysaccharide arabinogalactan. This biologically active water-soluble substance is a complex of sugars - arabinose and galactose [16], has a wide range of useful biological properties: immunobiological, hepatoprotective, gastroprotective and membrane-active $[17,18]$, mycogenic, prebiotic, antioxidant properties. It activates the oxidative metabolism of animal cells, it is a source of dietary fiber. It is safe in high dosages for animals of any age [19].

Considering that arabinogalactan is directly involved in the intermediate metabolism of the body as a glucoplastic material, promotes the synthesis of energy and increases the concentration of glucose, it can be used in feeding cows to compensate for the energy deficit [20], especially in the most physiologically intense periods (early postpartum period, retention). Due to the optimal supply of energy, the largest number of products can be obtained [4].

Among Siberian forest industry wastes, it is promising to use pine nutshells as a feed additive for farm animals. After processing cedar cones, there are tens of thousands of tons of shells (per one ton of nuts two tons of shells), which remain to rot in the taiga and at processing points.

It has been established that in the shell of pine nuts, there is a large number of valuable nutrients and biologically active substances: proteins, lipids, macroand micronutrients, tannides, flavonoids, polysaccharides. In addition, the shell has a low cost [21, 22].

To balance diets, it is necessary to add scarce components and feed additives that can increase the efficiency of feed absorption. Such biologically active preparations provide a more complete extraction of nutrients from existing feeds, break down the plant membrane, normalize the digestive system and provide the body with physiological needs at minimal feed costs [6].

Amylosubtilin G3x is produced by the Bacillus subtilis strain and contains a complex of amylolytic enzymes ( $\alpha$-amylase and associated enzymes - proteases, hemicellulase), due to the complex effect of which the step-by-step cleavage of native forms of plant feeds takes place The drug complements the enzymatic activity that positively affects the composition of the intestinal microflora, activates cicatricial digestion, increases the digestibility of feed [23].

In scientific research on veterinary medicine and zootechnology, when changing feeding conditions and studying the effect of new feeds and additives on animals, hematological and biochemical blood tests are widely used to assess their physiological condition and identify pathologies [24].

The aim of the article is to study the effect of coniferous flour, pine nutshell, arabinogalactan and
Amilosubtilin G3x on biochemical and hematological blood parameters of cows.

\section{Material and methods}

Scientific and economic experiments were conducted in the LLC "Plemzavod "Taezhny" Sukhobuzimsky district of the Krasnoyarsk region on black-motley cows at the age of the second calving (the first lactation phase) with an average daily milk productivity of $24 \mathrm{~kg}$ and an average live weight of $600-620 \mathrm{~kg}$. To conduct the experiment on the basis of analogues, three groups of dairy cows including 15 animals were formed. The experiment lasted 100 days.

Animals of all the experimental groups were fed with basic feed. In addition to the basic diet, cows experimental group 1 were fed with coniferous flour (50 $\mathrm{g} /$ goal / day), pine nutshell (50 g / goal / day) and Amilosubtilin G3x (5 g / goal / day), cows of experimental group 2 were fed with coniferous flour (50 g / goal / day.), pine nutshell (50 g / goal / day), Amilosubtilin G3x (5 g / goal / day) and arabinogalactan (5 g / goal / day).

The dosages of coniferous flour and pine nut shells were established as optimal in the previous studies on cows [21], the dosage of Amilosubtilin G3x was based on the manufacturer's recommendations [23], and the dose of arabinogalactan was chosen according to the literature [25].

To produce coniferous flour, logging waste was used - coniferous paws of Pínus sylvéstris which were mixed with an alcohol-toluene mixture and hot water in a microwave at $100^{\circ} \mathrm{C}$ for $20 \mathrm{~min}$. They were crushed to particles of $2 \mathrm{~mm}$. Pine nut shell (Pínus sibírica) was also crushed to particles of $4 \mathrm{~mm}$.

Amilosubtilin G3x (manufactured by PO Sibbiofarm LLC, Berdsk, Novosibirsk Region) is light brown powder, which contains dry amylolytic enzymes $(\alpha-$ amylase, protease, hemicellulase) (10-12\%) and excipients as fillers and stabilizers - wheat flour (5-6\%), precipitated chemical chalk (5-6\%), table salt.

Arabinogalactan (made in Russia) is fine pale cream powder without taste and smell. It has low viscosity, high stickiness, and is not toxic. It is a source of fiber and soluble water-retaining fibers, improves digestion, and helps to maintain health of the gastrointestinal tract. By $90 \%$ consists of larch arabinogalactan (from the lump part) [18].

All the additives were mixed and fed in a dry form once a day before morning milking.

The experimental cows were kept in the same barn in individual stalls in a tethered manner. Milking was automatic using milking machines twice a day.

The animals were fed according to the daily routine adopted on the farm. An analysis of the basic diet of experimental cows was carried out according to modern detailed feeding standards for lactating cows (Kalashnikov A.P. et al., 2003).

Blood was taken at the beginning and end of the experiment from caudal vein of 5 cows before morning feeding. Blood was tested by Krasnoyarsk Research 
Institute of Animal Husbandry - the Separate division FRC KSC SB RAS.

For a biochemical analysis, plastic vacuum tubes with a $9 \mathrm{ml}$ coagulation activator (PUTH, China) were used. Before the study, blood samples were precentrifuged in a ULAB laboratory centrifuge (UC-141D) at $2000 \mathrm{rpm}$ for $10-15$ minutes.

The serum was studied by the photometric method using a Chem Well 2910c automated biochemical and enzyme-linked immunosorbent analyzer (Awareness Technology, USA). The amount of total protein, albumin, iron, calcium, phosphorus, magnesium, chlorides, creatinine, amylase, glucose, triglycerides, cholesterol was determined. The studies were carried out using a set of reagents produced by JSC Vector-Best (Russia).

For the hematological analysis, $5 \mathrm{ml}$ tubes with anticoagulant K3EDTA (PUTH, China) were used. The morphological composition of blood was determined using an Abacus Junior 5 (Vet) blood analyzer (Diatron, Hungary) by the following methods: cell concentration and distribution of red blood cells, platelets, white blood cells and five subpopulations (lymphocytes, monocytes, neutrophils, eosinophils, basophils) - by the method of volumetric impedance in combination with a lysing reagent, the concentration of hemoglobin in erythrocytes - by the method of photometric absorption of light (photometric measurement of the light absorption of red blood cells).

The experiment was conducted according to the method by A.I. Ovsyannikova (1976). Biometric processing of the data was carried out according to the method by N.A. Plokhinsky (1969) using Analysis Package for Biometric Processing of Zootechnical Data (2015).

\section{Results and discussion}

The basic diet of cows included the following ingredients, kg: haylage of perennial grasses - 20; straw 6 ; barley -2 ; wheat -2.1 ; oats -2.5 ; sunflower meal -1 ; rapeseed cake - 1.8; molasses from rye grain - 1.8 ; chalk -0.1 ; table salt -0.08 . The dry matter content was 20.46 $\mathrm{kg}$.

An analysis of the basic diet (Table 1) showed that, depending on the weight of feed, coarse feed prevailed $\mathrm{i}$ (70.0\%), the proportion of concentrated feed was $30.0 \%$. However, the type of feeding is concentrated, as the share of concentrated feed is $52.0 \%$, while the share of coarse feed is $48.0 \%$.

According to Golovin A.V. (2016), a concentrated type of feeding helps to reduce the reserve alkalinity of blood and its other biochemical changes, prevent metabolic disorders. The high level of roughage reduces the digestibility of nutrients [26].

The content and ratio of the main nutrients corresponded to the norm [27], with an exception of digestible protein in 1 energetic feed units (EFU) the amount of which exceeded the norm by $1.6 \mathrm{~g}$. For every $100 \mathrm{~kg}$ of live weight, cows consumed $3.33 \mathrm{EFU}$ and $3.35 \mathrm{~kg}$ of dry matter.
Observations of the animals of the experimental groups showed that they willingly ate concentrated foods containing the additives.

Blood performs exceptional vital functions (protective, transport, thermoregulatory and others). The intensity and correctness of metabolic processes can be judged by the biochemical composition of blood [28] (Table 2).

Table 1. Diet analysis.

\begin{tabular}{|c|c|}
\hline Parameter & Value \\
\hline $\begin{array}{c}\text { Energetic feed units (EFU) in 1 kg of } \\
\text { dry matter }\end{array}$ & 0.99 \\
\hline Digestible protein in 1 EFU, g & 106.6 \\
\hline Crude fiber in dry matter, \% & 19.81 \\
\hline Crude fat in dry matter, \% & 3.80 \\
\hline Sugar in dry matter, \% & 9.80 \\
\hline Carotene in 1 kg of dry matter, mg & 48.23 \\
\hline Vitamin D in 1 kg of dry matter, ME & 185.11 \\
\hline Ca : P & $1.4: 1$ \\
\hline Sugar: Protein & $0.92: 1$ \\
\hline
\end{tabular}

Table 2. The results of biochemical studies of cow blood o $(\mathrm{M} \pm \mathrm{m}, \mathrm{n}=5)$.

\begin{tabular}{|c|c|c|c|}
\hline \multirow{2}{*}{ Parameter } & \multicolumn{3}{|c|}{ Group } \\
\hline & control & experimental 1 & experimental 2 \\
\hline $\begin{array}{c}\text { Total protein, } \\
\mathrm{g} / 1\end{array}$ & $83.64 \pm 2.27$ & $84.23 \pm 5.28$ & $85.90 \pm 3.96$ \\
\hline Albumin, g/l & $31.72 \pm 1.39$ & $32.34 \pm 0.86$ & $32.66 \pm 0.79$ \\
\hline Iron, mmol/l & $28.18 \pm 0.91$ & $29.60 \pm 0.23$ & $29.18 \pm 0.81$ \\
\hline $\begin{array}{c}\text { Calcium, } \\
\mathrm{mmol} / \mathrm{l}\end{array}$ & $2.67 \pm 0.12$ & $2.55 \pm 0.08$ & $2.71 \pm 0.15$ \\
\hline $\begin{array}{c}\text { Phosphorus, } \\
\text { mmol/l }\end{array}$ & $2.26 \pm 0.19$ & $2.25 \pm 0.18$ & $2.49 \pm 0.24$ \\
\hline $\begin{array}{l}\text { Magnesium, } \\
\text { mmol /l }\end{array}$ & $1.16 \pm 0.02$ & $1.20 \pm 0.03$ & $1.19 \pm 0.01$ \\
\hline $\begin{array}{c}\text { Chlorides, } \\
\text { mmol/l }\end{array}$ & $98.00 \pm 2.76$ & $91.00 \pm 2.06$ & $93.80 \pm 1.39$ \\
\hline Creatinine & $94.18 \pm 8.58$ & $85.68 \pm 10.78$ & $99.84 \pm 3.41$ \\
\hline Amylase, u/l & $13.00 \pm 3.48$ & $13.50 \pm 2.75$ & $12.40 \pm 2.28$ \\
\hline $\begin{array}{c}\text { Glucose, } \\
\mathrm{mmol} / \mathrm{l}\end{array}$ & $3.52 \pm 0.23$ & $3.56 \pm 0.21$ & $3.66 \pm 0.28$ \\
\hline $\begin{array}{c}\text { Triglycerides } \\
\text {,mmol/l }\end{array}$ & $0.09 \pm 0.02$ & $0.09 \pm 0.03$ & $0.10 \pm 0.02$ \\
\hline $\begin{array}{l}\text { Cholesterol, } \\
\text { mmol/ll }\end{array}$ & $5.22 \pm 0.45$ & $5.10 \pm 0.29$ & $5.20 \pm 0.68$ \\
\hline
\end{tabular}

All the blood parameters were within the physiological norm. Moreover, in the blood serum of experimental group 2, compared with the control and 1st 
experimental groups, there was a tendency to increase the concentration of total protein by 2.7 and $2.0 \%$, albumin - by 3.0 and $1.0 \%$ calcium - by 1.5 and $6.3 \%$, phosphorus - by 10.2 and $10.7 \%$, creatinine - by 6.0 and $16.5 \%$, glucose - by 4.0 and $2.8 \%$ and triglycerides - by $11.1 \%$.

The tendency to improve mineral and carbohydrate metabolism in the body of cows of experimental group 2 is due to the fact that coniferous flour and pine nutshell contain a complex of nutrients (vitamins and minerals) in an easily accessible form, and arabinogalactan contributes to an increase in the concentration of glucose, which favorably affects the physiological state of animals.

The efficiency of these feed additives is enhanced through the use of Amilosubtilin G3x, which, according to Danilova N.V., Lavrentiev A.Yu. (2017), increases the productive effect of feed and helps to intensify metabolic processes [29].

Table 3. Hematological blood counts $(M \pm m, n=5)$.

\begin{tabular}{|c|c|c|c|}
\hline & \multicolumn{3}{|c|}{ Group } \\
\cline { 2 - 4 } Parameter & control & $\begin{array}{c}\text { experimental } \\
1\end{array}$ & $\begin{array}{c}\text { experimental } \\
2\end{array}$ \\
\hline $\begin{array}{c}\text { White blood } \\
\text { cells (WBC), } \\
109 \text { cl/l }\end{array}$ & $6.41 \pm 0.38$ & $7.10 \pm 0.27$ & $7.26 \pm 0.28$ \\
\hline $\begin{array}{c}\text { Red blood cells } \\
\text { (RBC), 1012 cl/1 }\end{array}$ & $6.41 \pm 0.26$ & $6.72 \pm 0.39$ & $6.05 \pm 0.44$ \\
\hline $\begin{array}{c}\text { Hemoglobin } \\
\text { (HGB), g/l }\end{array}$ & $92.75 \pm 3.34$ & $85.00 \pm 2.78$ & $83.41 \pm 2.15$ \\
\hline $\begin{array}{c}\text { Hematocrit } \\
\text { (HCT), \% }\end{array}$ & $28.88 \pm 2.80$ & $29.73 \pm 2.89$ & $28.52 \pm 3.42$ \\
\hline $\begin{array}{c}\text { The average } \\
\text { volume of red } \\
\text { blood cells } \\
\text { (MCV), fl }\end{array}$ & $45.28 \pm 2.22$ & $46.81 \pm 3.32$ & $47.15 \pm 3.34$ \\
\hline $\begin{array}{c}\text { Average } \\
\text { hemoglobin } \\
\text { content in the red } \\
\text { blood cell (MCH), } \\
\text { pg }\end{array}$ & $13.93 \pm 0.56$ & $14.28 \pm 0.57$ & $14.07 \pm 0.39$ \\
\hline $\begin{array}{c}\text { Average } \\
\text { concentration of } \\
\text { hemoglobin in red } \\
\text { blood cells } \\
\text { (MCHC), g / } 1\end{array}$ & $306.10 \pm$ \\
\hline $\begin{array}{c}\text { Red blood cell } \\
\text { distribution } \\
\text { (RDWc), \% }\end{array}$ & $19.44 \pm 1.10$ & $19.34 \pm 0.91$ & $19.26 \pm 0.96$ \\
\hline $\begin{array}{c}\text { Platelets (PLT), } \\
109 \text { cells/l }\end{array}$ & $238.05 \pm$ & $210.6 \pm$ & $218.22 \pm$ \\
\hline $\begin{array}{c}\text { Platelet distribution } \\
\text { (PDWc), \% }\end{array}$ & $27.31 \pm 1.07$ & $30.71 \pm 1.93$ & $32.06 \pm 2.02$ \\
\hline $\begin{array}{c}\text { Average platelet } \\
\text { volume (MPV), } \\
\text { fl }\end{array}$ & $4.62 \pm 0.65$ & $6.21 \pm 1.08$ & $5.80 \pm 1.04$ \\
\hline $\begin{array}{c}\text { Thrombocrit } \\
\text { (PCT), \% }\end{array}$ & $0.11 \pm 0.01$ & $0.11 \pm 0.01$ & $0.10 \pm 0.01$ \\
\hline LPCR), \% & $70.46 \pm 5.91$ & $60.26 \pm 7.75$ & $59.65 \pm 7.05$ \\
\hline
\end{tabular}

\begin{tabular}{|c|c|c|c|}
\hline $\begin{array}{c}\text { Lymphocytic } \\
\text { index (LYMI) }\end{array}$ & $1.54 \pm 0.18$ & $1.38 \pm 0.14$ & $1.29 \pm 0.10$ \\
\hline $\begin{array}{c}\text { Neutrophilic } \\
\text { lymphocytic ratio } \\
\text { (NLR) }\end{array}$ & $0.64 \pm 0.15$ & $0.80 \pm 0.20$ & $0.74 \pm 0.14$ \\
\hline
\end{tabular}

Note - * Differences are statistically significant at $\mathrm{P} \leq 0.05$.

Table 3 presents the hematological parameters of cow blood.

After feeding the feed additives, all the hematological parameters were within the physiological norm [30] and varied insignificantly within the limits of natural biological values.

In determining the protective functions of the body, the study of the leukocyte formula is of great importance. This is especially important when studying the effect of new feeds [31].

Table 4. Cow blood leukogram ( $\pm m, n=5)$.

\begin{tabular}{|c|c|c|c|}
\hline \multirow{2}{*}{$\begin{array}{c}\text { White blood } \\
\text { cells } \%\end{array}$} & \multicolumn{3}{|c|}{ Group } \\
\cline { 2 - 4 } & control & $\begin{array}{c}\text { experimental } \\
1\end{array}$ & $\begin{array}{c}\text { experimental } \\
2\end{array}$ \\
\hline Basophils & $1.16 \pm 0.25$ & $0.52 \pm 0.19$ & $0.79 \pm 0.23$ \\
\hline Eosinophils & $2.36 \pm 0.38$ & $1.71 \pm 0.53$ & $1.96 \pm 0.30$ \\
\hline Neutrophils & $36.25 \pm 3.36$ & $38.72 \pm 2.97$ & $41.23 \pm 2.36$ \\
\hline Lymphocytes & $58.43 \pm 2.49$ & $54.24 \pm 1.92$ & $51.52 \pm 1.50^{*}$ \\
\hline Monocytes & $5.03 \pm 0.58$ & $2.96 \pm 0.45$ & $4.81 \pm 0.74$ \\
\hline Blood profile & $1 y m p h a t i c$ & lymphatic & lymphatic \\
\hline
\end{tabular}

An analysis of the leukogram showed that the experimental cows had a lymphocytic blood profile (the share of lymphocytes was 51.52-58.43\%). Among the granulocytes, neutrophils prevailed (36.25-41.23\%). In general, the leukogram corresponded to the leukocyte formula of healthy animals, which suggests that the cows had a stable homeostasis.

The results obtained are consistent with the results obtained by Novikova T.V., Britvina I.V. et al. (2019), who found that it had a positive effect on the general clinical, biochemical, hematological and immunological parameters of blood, calving quality, milk productivity and quality. In the blood of cows, the carotene content was more stable, which indicated a better vitamin supply of the body [32].

Korotky V.P., Ryzhov V.A. et al. (2018) studying the effect of coniferous energy supplements on the physiological and biological parameters of lactating cows established an improved physiological and biochemical status, the total protein content increased by $1.4-3.3 \%$, glucose - by $5.9-19.8 \%$, carotene - by $13.2-$ $31.6 \%$.

The authors argue that the natural coniferous extract, which is part of the coniferous energy supplement, has a positive effect on metabolism, and its use in the first 
phase of lactation helps to prevent diseases, improve the functioning of the gastrointestinal tract, liver functions, and increases the longevity of animals [33].

When feeding arabinogalactan to Kholmogory calves and determining the dynamics of antioxidant system activity, concentration of triacylglycerols, total cholesterol and its fractions, Galochkin V.A., Galochkina V.P., Maksimenko S.V. (2008) revealed an increase in the adaptive-protective functions of the body and an increase in the live weight of calves [34].

\section{Conclusion}

It was found that coniferous flour, pine nutshell, arabinogalactan and enzyme preparation Amilosubtilin G3x do not have a negative effect on the metabolism and can be used in feeding cows.

We are grateful to D.A. Zykov, Director General of LLC "Plemzavod "Taezhny", E.V. Zyablitseva, a chief breeder livestock engineer, I.V. Petirimova, a animal breeder for their assistance in our research.

This work was financially supported by the Ministry of Science and Higher Education of Russia, state registration number R\&D: AAAA-A19-119012290066-7.

\section{References}

1. A.Yu. Lavrentiev, D.Yu. Smirnov, Compound feed, 8, 69-71 (2013)

2. V.R. Minibaev, R.R. Sayfullin, Bulletin of Orenburg State Agrarian University, 6, 186-189 (2017)

3. S.A. Rukol, Zootechnical science of Belarus, 41, 326-330 (2006)

4. R.F. Shaidullin, Scientific notes of Kazan State Academy of Veterinary Medicine named after N.E. Bauman, 4, 421-425 (2012)

5. Krasnoyarsk Regional Statistical Yearbook, 1.37.5, 257 (Krasnoyarskstat, 2019)

6. V.P. Korotkiy, Yu.N. Prytkov, S.S. Marisov, N.I. Gibalkina, A.A. Kistina, N.P. Chernobrovkina, E.V. Robonen, Pat. RU 2515015 (2014)

7. A. Sukhodolov, Science in Siberia, 23, 6-7 (2003)

8. N.V. Bogolyubova, V.N. Romanov, Veterinary medicine, livestock and biotechnology, 4, 79-87 (2018)

9. V.P. Korotkiy, N.V. Bogolyubova, E.S. Ryzhova, V.A. Ryzhov, Farm News, 4, 58-59 (2018)

10. Yu.N. Prytkov, A.A. Kistina, M.Yu. Chervyakov, Agrarian Scientific Journal, 10, 17-20 (2015)

11. M.F. Tomme, Feed diets and feeding rates for farm animals, 384 (1963)

12. A. Meral, P. Tuncel, E. Surmen-Gur, Pediatr. Hematol. Oncol., 17, 687-693 (2000)

13. S. S. Tarasov, A.S. Koryagin, A.A. Gavrilova, Bulletin of Perm University. Series: Biology, 4, 469475 (2017)
14. A.L. Vorobiev, A.A. Kalachev, S.V. Zalesov, Forests of Russia and forestry economy, 3, 65-72 (2018)

15. V.A. Tereshchenko, E.A. Ivanov, O.V. Ivanova, Russian Agricultural Science, 6, (2019) DOI: 10.31857/S2500-26272019645-49

16. N.A. Oleinikov, Ch.B. Kusheev, S.S. Lomboeva, S.A. Pavlov, Bulletin of IAU, 79, 130-138 (2017)

17. E.N. Medvedev, V.A. Babkin, L.A. Ostroukhova, Chemistry of Plant Raw Materials, 1, 27-37 (2003)

18. Ch.B. Kusheev, V.A. Babkin, B.I. Dorzhiev, S.S. Lomboeva, E.N. Medvedev, A.N. Lysenko, The use of nanostructured drugs for the prevention and treatment of young farm animals: guidelines, 31 (2010)

19. Yu.P. Fomichev, L.A. Nikanova, S.A. Lashin, Bulletin of the Michurinsk State Agrarian University, 3, 21-32 (2018)

20. N.P. Buryakov, A.V. Kosolapov, Russian Veterinary Journal, 3, 31-36 (2013)

21. O.V. Ivanova, E.A. Ivanov, V.A. Tereshchenko L.V. Efimova, T.V. Zaznobina, O.A. Frolova, IOP Conference Series: Earth and Environmental Science, 341, 012095 (2019) DOI: 10.1088/17551315/341/1/012095

22. Yu.R. Savelyev, A.N. Kryazhov, M.C. Bogomolov, V.L. Ivasenko, V.T. Novikov, Chemistry of plant materials, 4, 61-64 (2003)

23. Enzyme preparation Amilosubtilin, retrieved from: http://www.sibbio.ru/catalog/zhivotnovodstvo/ferme ntnyy-preparat-amilosubtilin/

24. T.A. Makashova, T.A. Nikiforova, A.A. Ivanov, Bulletin of beef cattle breeding, 63, 85-94 (2010)

25. Yu.P. Fomichev, L.A. Nikanova, V.I. Dorozhkin, A.A. Torshkov, A.A. Romanenko, E.K. Yeskov, A.A. Semenova, V.A. Gonotsky, A.V. Dunaev, G.S. Yaroshevich, S.A. Lashin, N.I. Stolnaya, Dihydroquercetin and arabinogalactan - natural bioregulators in human and animal life, application in agriculture and food industry: monograph, 702 (2017)

26. A.V. Golovin, Bulletin of Samara State Agricultural Academy, 2, 66-70 (2016) DOI: 10.12737/19063

27. A.P. Kalashnikov, V.I. Fisinin, V.V. Scheglov, N.I. Kleimenov, Norms and diets of feeding farm animals. Reference guide, 456 (2003)

28. M.M. Nikitina, V.I. Raitskaya, G.A. Rusinovich, Scientific support of animal husbandry in Siberia: materials of the III Intern. scientific-practical conf., 195-199 (2019)

29. N.V. Danilova, A.Yu. Lavrentiev, Theory and Practice of Meat Processing, 3 (2017) DOI: 10.21323/2414-438X-2017-2-3-31-38, 31-38

30. M.A. Medvedev, Clinical Veterinary Laboratory Diagnostics. Handbook for Veterinarians, 416 (2013)

31. D.V. Vorobiev, Natural sciences, 2, 113-120 (2010) 
32. T.V. Novikova, I.V. Britvina, E.A. Ryzhakina, V.P. Korotkiy, Dairy Messenger, 1, 27-39 (2019) DOI: 10.24411/2225-4269-2019-00003

33. V.P. Korotkiy, V.A. Ryzhov, N.P. Buryakov, N.A. Yurina, Yu.N. Kolesnik, Collection of scientific papers of the Krasnodar Scientific Center for Zootechnics and Veterinary Medicine, 7(1), 271-276 (2018)

34. V.A. Galochkin, V.P. Galochkina, S.V. Maksimenko, Agricultural Biology, 4, 89-95 (2008) 